\title{
GLOBALISASI DAN PENGARUHNYA TERHADAP PEMBAHARUAN HUKUM EKONOMI DI INDONESIA
}

\author{
M.Doing \\ PT. PLN (Persero) Wilayah Kalimantan Barat \\ Email: doing_muhammad@yahoo.com
}

\begin{abstract}
The substance of the national economic law reformation must be based on Pancasila and the Indonesian Constitution 1945. Ideally, the implementation of it must be able to accommodate the interests of the capitalist market and the economy of social market. The economic system give stress to good cooperation and also competition. In the economic democracy, there is no place for negative traits of liberal-capitalist which create the survival of the fittest, and also the economic system of socialist-communist.
\end{abstract}

Keywords: Globalization; Economic Law.

\begin{abstract}
Abstrak
Substansi pembaharuan hukum ekonomi nasional harus bersendikan Pancasila dan UUD 194. Idealnya dalam implementasi, hukum ekonomi nasional harus dapat mengakomodasi kepentingan pasar kapitalistik dan ekonomi pasar sosial secara proporsional. Sistem ekonomi yang demikian, menekankan pentingnya kerja sama di satu pihak dan sekaligus juga persaingan di pihak lainnya. Dalam demokrasi ekonomi berarti tidak ada tempat bagi ciri-ciri negatif liberalisme-kapitalisme yang menciptakan survival of the fittest, maupun sistem ekonomi sosialis-komunis .
\end{abstract}

Kata Kunci: Globalisasi; Hukum Ekonomi.

\section{A. Pendahuluan}

1. Latar Belakang Permasalahan

Indonesia sebagai negara yang berada di wilayah Asia Pasific harus berupaya untuk mempersiapkan diri dan mengantisipasi berbagai kemungkinan yang berkaitan dengan dinamika ekonomi dan perdagangan. Dalam hal ini hukum, terutama hukum yang berkaitan dengan ekonomi, memegang peranan penting untuk mendukung aktivitas ekonomi dalam negeri yang dilakukan antar negara. Untuk itu dibutuhkan langkahlangkah yang mengarah pada perlunya merumuskan hukum ekonomi melalui upaya pemeliharaan, penciptaan, dan pembaharuan hukum, terlebih pada saat sekarang, ketika negara masih juga belum bebas dari dampak krisis ekonomi.

Dalam tataran globalisasi ekonomi yang begitu progresif, maka akomodasi terhadap hukum yang dapat mendukungnya adalah model hukum bertipe responsif, yang lebih menitik-beratkan pada aspek praktisadaptif. ' Jadi implementasinya akan bersinergi dengan basis sosial perkembangan bisnis. Globalisasi yang merupakan pembentukan sistem kapitalisme dunia dan liberalisasi perdagangan, di dalamnya tentu terjadi hubungan kerjasama antara negara kuat dengan negara berkembang di berbagai kegiatan termasuk hukum. Perubahan ke arah global dan munculnya berbagai aktivis yang trans-nasional, menghendaki adanya penyesuaian melalui restrukturisasi dalam proses ekonomi dari nasional menjadi internasional.

Peranan negara pada era perdagangan bebas terkesan semakin tereleminasi, orang akan terus bebas membentuk jaringan sesama pelaku usaha antara negara (global). Esensi semakin menguatnya perdagangan oleh pelaku usaha atau individu antara negara

\footnotetext{
1.Zudan Arief Fakrulah, 2000, Membangun Hukum Yang Berstruktur Sosial Indonesia Dalam Kancah Trends
} Globalisasi, Bandung, PT. Citra Aditya Bakti, hlm 55. 
(perdagangan internasional) pada dasarnya sesuai filosofi dagang yang menegaskan "berdagang merupakan suatu kebebasan fundamental (fundamental freedom), dengan kebebasan ini, siapa saja harus memiliki kebebasan untuk berdagang. Kebebasan ini tidak boleh dibatasi oleh adanya perbedaan agama, suku, kepercayaan, sistem hukum dan lain-lain. Hal ini juga sejalan dengan penganut pasar bebas yang menekan bahwa kemerdekaan berniaga merupakan salah satu hal alamiah (natural right). ${ }^{2}$

Perkembangan yang begitu pesat dalam pasar bebas, pasar akhirnya dipenuhi dengan berbagai jenis dan variasi barang dan/atau jasa yang pada umumnya merupakan produk sejenis maupun yang sifatnya komplementer satu dengan yang lainnya. Diversifikasi produk yang begitu luas dan didukung oleh kemajuan teknologi dan infrastruktur yang baik menyebabkan ruang gerak arus transaksi barang dan/atau jasa semakin luas melintasi wilayah suatu negara. Konsumen akhirnya dihadapkan pada suatu pilihan atas barang dan/atau jasa yang bervariasi baik yang berasal dari produk domestik maupun yang berasal dari luar negeri. Kondisi tersebut, disatu sisi dapat mendatangkan keuntungan pihak konsumen, karena konsumen memiliki keleluasaan dalam membeli barang yang berkualitas dengan harga bersaing untuk memenuhi kebutuhannya.

Konvergensi sistem ekonomi yang akomodatif, melalui suatu regulasi dan kebijakan mutlak diperlukan, sehingga tercapai efesiensi secara ekonomis maupun sosial. Hal ini dilakukan dalam rangka mengeleminasi maraknya problem sosial, seperti tingginya disparitas antara pelaku usaha, dan semakin kontras jarak antara yang kaya dan miskin dan lain sebagainya. Terkait dengan pembaharuan hukum ekonomi di masa yang akan datang, substansinya tidak hanya berdasar pada kepentingan pasar kapitalistik semata, namun juga mengakomodasi ekonomi pasar sosial.

Bertitik tolak dari rumusan latar belakang diatas, dengan tema sentral tentang konvergensi sistem ekonomi di era globalisasi dan implementasinya terhadap hukum ekonomi Indonesia, maka penting untuk dibahas permasalahan sebagai berikut: (1) Apakah terjadi konflik kepentingan antara negara maju dan berkembang dalam era globalisasi ? (2) Bagaimanakah pengaruh konvergensi sistem ekonomi Indonesia di era globalisasi dan implementasinya terhadap pembaharuan hukum ekonomi?

\section{Metode Penelitian}

Mengingat cakupan dan karakteristik dari hukum ekonomi yang luas, Hal itu terjadi sebagai konsekuensi perkembangan pesat hubungan ekonomi, perdagangan, dan bisnis internasional. Apalagi globalisasi ekonomi dunia, dimana negara-negara seakan telah menjadi satu wilayah pasar yang sangat luas dan bersifat tanpa batas (borderless), maka pendekatan interdipliner dianggap yang memadai. Untuk itu penelitian ini menggunakan metode sosio-legal.

\section{Kerangka Teori}

Dalam tataran globalisasi ekonomi yang begitu progresif, maka akomodasi terhadap hukum yang dapat mendukungnya adalah model hukum bertipe responsif, yang lebih menitik-beratkan pada aspek praktisadaptif. Jadi implementasinya akan bersinergi dengan basis sosial perkembangan bisnis. Zudan Arief Fakrullah menegaskan pada era globalisasi, pembangunan dan pembinaan hukum yang sesuai dengan trends internasional terasa semakin mendesak. ${ }^{4}$

Urgensi hukum yang berlaku dalam pembinaannya harus memperhatikan unsurunsur kecenderungan internasional, politis, sosiologis, filosofis, yuridis dan praktis adaptif. Membangun hukum agar sesuai dengan prinsip praktis adaptif, membutuhkan sikap kritis dan berpikir terbuka, karena dalam struktur yang ada selama ini banyak nilai-nilai ada tidak mudah untuk menampung dalam format sistem hukum yang responsive. Realitas yang ada saat ini adalah adnya missinkronisasi antara nilai-nilai dan norma yang berlaku.

\footnotetext{
2. Huala Adolf, 2002,Hukum Ekonomi Internasional Suatu Pengantar, Jakarta, Rajawali Pers hlm 3.

3. Nimrot Siahaan, "Pengaruh Hukum Terhadap Globalisasi Dan Pembangunan Ekonomi”, Jurnal Ilmiah Research 4 Sainis, Vol. 1, No. 1, Januari 2015, hlm 1-5.

4. Zudan Arief Fakrullah, Op. cit, hlm 53.
} 
Antara nilai dan norma tidak jumbuh.

Dalam tataran praksis globalisasi ekonomi, mengenai kemakmuran yang hanya dapat diwujudkan melalui liberalisasi ekonomi ternyata tidak pernah terbukti secara nyata. Arief Hidayat dalam konteks tersebut menegaskan bahwa globalisasi dengan cara atau pola yang tidak berbentuk dan tidak terarah seperti sekarang juga menyebabkan negara-negara berkembang sulit untuk berdiri sama tinggi dengan negara-negara maju. Hal ini disebabkan adanya kekuatan tersembunyi di balik globalisasi (yang sebenarnya merupakan kapitalisme, yang pada perkembangannya yang terakhir merupakan neoliberalisme) tersebut yang tidak lain adalah "kebijakan dan kontrol" negaranegara maju. ${ }^{5}$

\section{B. Hasil dan Pembahasan \\ 1. Penetrasi Globalisasi: Negara Maju ke Negara Sedang Berkembang.}

Globalisasi pada dasarnya adalah upaya untuk mengintegrasikan ekonomi nasional ke dalam ekonomi global yang kapitalistik. Di dalamnya ada kekuatan global yang mampu mendesakkan norma-norma liberal dan kapitalistik di bidang ekonomi kepada negara-negara lain, khususnya negara-negara di Dunia Ketiga. Globalisasi ekonomi memberikan peluang bagi negara industri untuk memperluas ekspansi ekonominya serta meraup keuntungan yang tak terbatas, namun sebaliknya globalisasi membuat posisi negara miskin menjadi semakin tersudutkan oleh lalu lintas barang,jasa,dan modal yang masuk dengan bebas, sehingga mematikan perekonomian domestik. Kondisi seperti ini, dalam relasi antara negara maju dan negara dunia ketiga selalu terjadi konflik kepentingan ekonomi.

Globalisasi ekonomi yang diwujudkan melalui liberalisasi, dimana nilai tertinggi manusia adalah perkembangan dan kebahagiaan individu (individualisme). Jadi, menempatkan kebebasan individu adalah nilai tertinggi. Ekspektasi yang berlebihan inilah yang telah menyeret negara berkembang kedalam pusaran liberalisasi ekonomi yang berbahaya. Setiap negara dihadapkan pada tekanan untuk mengadopsi norma-norma ekonomi liberal dan demokrasi. Menurut Zain Mualana, hal tersebut disebabkan standar modernisasi yang terdapat di dunia barat dianggap sebagai satusatunya model yang akan menciptakan kemakmuran. Dalam pembangunan etik, cara dan tujuan pembangunan menjadi sama penting yang memiliki signifikansi yang sama kuat. Cara atau alat yang tepat dalam mendorong proses pembangunan akan menentukan hasil pembangunan yang maksimal. ${ }^{6}$

Akibatnya adalah cara atau instrumen menjadi subordinat dalam sebuah proses pembangunan, sehingga target pembangunan harus dapat tercapai meskipun menggunakan cara yang tidak sehat bagi perkembangan masyarakat dan negara ke depan. Keberhasilan pembangunan yang bersifat materialistik seperti pertumbuhan ekonomi yang tinggi, stabilitas keuangan, neraca perdagangan, dan stabilitas nilai mata uang. Indikator keberhasilan pembangunan yang lebih bersifat substansial seperti pemerataan pembangunan, distribusi kesejahteraan masyarakat, hingga pembangunan kualitas hidup manusia dan lingkungan hidup menjadi tersisihkan dan bahkan sengaja dilupakan. ${ }^{7}$

\section{G lobalisasi M enciptakan Ketergantungan}

Globalisasi ekonomi secara prinsip mustahil dapat dipisahkan dari paham ekonomi neoliberal, Artinya berbicara mengenai globalisasi ekonomi sama artinya dengan berbicara mengenai penyebarluasan dan pelaksanaan konsep ekonomi neoliberal di seluruh penjuru dunia. ${ }^{8}$ Pada aspek ekonomi, pergerakan barang dan jasa yang begitu bebas dan investasi asing yang semakin meningkat ternyata telah memicu meningkatnya ketergantungan ekonomi yang tinggi dari negara pinggiran terhadap negaranegara pusat. Ketergantungan ekonomi ini,

\footnotetext{
5. Arief Hidayat, "Bernegara Itu Tidak Mudah: Dalam Perspektif Hukum dan Politik", Pidato Pengukuhan Jabatan Guru Besar, Universitas Diponegoro Semarang, hlm 9.

6. Zain Maulana, 2010, Jerat Globalisasi Neoleberal; Ancaman bagi Negara Dunia Ketiga, Yogyakarta, Biak, hlm 10.

7. Ibid, hlm 11.

8. Francis Wahono, 2003, Neoliberalisme, Yogyakarta, Cindelaras Pustaka Rakyat Cerdas, hlm 8.
} 
pada akhirnya akan membentuk suatu pola hubungan yang tidak seimbang antar negaranegara. Ketidakseimbangan ini sebagai wujud dari dominasi dan hegemoni negara kaya atas negara miskin. ${ }^{9}$

Globalisai ekonomi di konstruksi untuk menciptakan kesenjangan dan ketergantungan setiap negara terhadap ekonomi negara maju. Perputaran ekonomi dunia yang hanya dikuasai oleh beberapa negara yang memiliki kekuatan industri dan korporasi-korporasi besar, membuat ketergantungan itu menjadi semakin nyata. Tentu jika dilihat dari perspektif kritis, ketergantungan terhadap asing tidak lebih baik daripada menciptakan kemandirian. ${ }^{10}$

Negara sedang berkembang yang sangat tergantung terhadap suntikan penanaman modal asing selalu berdampak pada dua sisi yang berlawanan. Ekonomi tumbuh dengan cepat di satu sisi, namun menciptakan kerentanan yang endemik di lain sisi. Kerentanan ini akan menjadi bencana maha dahsyat ketika moda-modal asing yang menumpuk ditarik kembali oleh para investor, sehingga yang tersisa hanyalah krisis ekonomi yang berujung pada kemiskinan yang permanen, yang oleh Zain Mualana merupakan bagian yang inheren dari adanya proses globalisasi yang semakin massif. ${ }^{11}$

Doktrin yang menyatakan bahwa kemakuran hanya dapat di wujudkan melalui ekonomi pasar bebas telah menutup mata banyak negara bahwa sesungguhnya globalisasi tidak selamanya menghasilkan kemakmuran, tetapi sebaliknya globalisasi berpeluang besar menciptakan kesenjangan dan kemiskinan yang belum pernah terjadi sepanjang sejarah kehidupan manusia. ${ }^{12}$

Globalisasi ekonomi tidak saja berbahaya karena dampaknya dalam menciptakan kemiskinan, namun lebih daripada itu globalisasi noeliberal sesungguhnya merupakan suatu kerangka ideologis yang dengan sengaja diproduksi untuk menciptakan imperialisme. Arief
Hidayat, kembali mengingatkan tentang dampak negatif dari globalisasi, menurutnya: "Globalisasi tidak selalu membawa manfaat bagi semua orang, bahkan untuk hal-hal yang memang terbukti menghasilkan manfaat saja selalu ada sekelompok orang, bangsa atau negara yang dirugikan. Mereka inilah korban globalisasi. Disadari atau tidak, kemiskinan global, hilangnya hak untuk mendapatkan pendidikan, gizi buruk dan sebagainya merupakan imbas dari tata dunia yang tidak memberikan ruang bermain yang sama atau seimbang dan tempat yang berkeadilan bagi seluruh penduduk dunia. Sementara itu, ketersediaan sumber daya alam yang semakin terbatas karena ekploitasi oleh manusia dan prediksi akan terjadinya bencana yang diakibatkan oleh perubahan iklim berupa pemanasan global (global warming atau climate change) telah menimbulkan kekhawatiran seluruh penduduk dunia, tidak hanya dari negara-negara miskin tapi juga negaranegara industri, dan hal ini telah memicu ketegangan dan konflikkonflik untuk memperebutkan sumber daya alam yang masih ada. Belum lagi masalah kekurangan air, pangan dan energi." 13

Ragam dampak negatif dari globalisasi ekonomi diatas, tentunya sangat terasa pengaruhnya bagi negara-negara miskin dan sedang berkembang, yang pada umumnya belum siap untuk menerima globalisasi ekonomi sebagai jalan utama bagi negara dalam meraih kesejahteraan, sehingga proses globalisasi cenderung memukul perkembangan ekonomi di negara dunia ketiga akibat persaingan bebas yang tidak adil.

3. Konvergensi Sistem Ekonomi Domestik dan Global Dalam Pembaharuan Hukum Ekonomi Indonesia sebagai bagian dari

9. H.M. Safi'I, 2009, Perencanaan Pembangunan Daerah (Kajian dan Aplikasi Rencana Pembangunan Jangka Menengah Daerah (RPJMD) di Kabupaten Hulu Sungai Selatan). Malang, Averroes Press, hlm 67.

10. Laili Bariroh, "Politik Hukum Nasional Dan Hegemoni Globalisasi Ekonomi”, Jurnal Review Politik, Vol. 2, No. 2,

11. Desember 2012, hlm 196-218.

11. Zain Maulana, Op.cit, hlm 9.

12. Ibid, hlm 12.

13. Ibid, hlm 10. 
masyarakat dunia tidak bisa melepaskan diri dari arus transformasi global, namun disisi sebagai negara berdaulat dengan ragam kemajemukannya (pluralitik) harus tetap eksis dan terjaga. Setiap usaha pemikiran maupun tindakan yang mencoba bergulat dengan persoalan sosial Indonesia akan selalu dihadapkan pada suatu kesulitan yang relatif permanen, yaitu masalah kesatuan dan kebhinekaan.

Mengingat yang menyeluruh (kesatuan) tidak dapat dengan tuntas mempresentasikan pluralitas dan bagianbagiannya. Demikian pula pluralitas dan bagian-bagiannya tidak dapat dijumlahkan begitu saja untuk mencakup yang menyeluruh. Baik yang menyeluruh maupun bagian-bagiannya memiliki struktur, nilai dan sistem serta dinamikanya sendiri. Akibatnya itulah mengapa para orientalis sering terjebak pada kesimpulan yang tidak banyak benarnya mengenai ciri masyarakat Indonesia yang dijuluki sebagai masyarakat yang dualistis, paradoksal dan antagonis. ${ }^{14}$

Keunikan Indonesia yang demikian ini, memposisikan dalam konteks pembangunan tentunya tidak bisa dilakukan secara linier, seperti yang yang terjadi pada pembangunan masayarakat di Eropa. Untuk teorinya Rostow, yang menyebutkan bahwa pembangunan, sebagai proses evolusi perjalanan dari tradisional ke modern, dan selalu berjalan linier ke depan. Pikiran ini kemudian menjelma menjadi apa yang disebutnya sebagai the five stage scheme. Asumsinya adalah semua masyarakat Barat pernah mengalami tradisional dan akhirnya menjadi modern. Sikap manusia yang tradisional, oleh Rostow, dianggap sebagai masalah, dan karenanya harus dipecahkan melalui pembangunan. Tahapan pertama proses ini adalah, (a) masyarakat tradisional, (b) masyarakat prakondisi tinggal landas, (c) masyarakat tinggal landas, (d) masyarakat pematangan pertumbuhan, (e) masyarakat modern yang dicita-citakan, yakni masyarakat industri, di mana di dalamnya tercipta masyarakat modern masa konsumsi tinggi (hight mass consumption). ${ }^{15}$
Komitmen pemerintah terhadap pelaksanaan sila kelima benar-benar diuji di era iklim persaingan bebas dan globalisasi sekarang ini. Berbagai perjanjian bilateral dan multilateral dalam kerangka integrasi perekonomian regional atau global mengikat negara-negara pada kesepakatan dan aturanaturan main baru, yang tak jarang menabrak kepentingan nasional. Tidak heran, tak sedikit dari kita menuding sistem kapitalis, persaingan bebas, dan globalisasi sebagai penghancur sendi-sendi ekonomi dan kedaulatan negara dalam mewujudkan pembangunan untuk menyejahterakan rakyat.

Dalam konteks sistem ekonomi kedepan, pilihan antara sistem ekonomi kapitalis, yang mengkultuskan pasar bebas atau sistem ekonomi Pancasila, yang cenderung berpihak pada ekonomi rakyat sebagaimana telah ditegaskan dalam Pasal 33 UUD 1945. Bukanlah suatu pilihan yang bersifat kategoris. Menurut Gregory dan Stuartsistem ekonomi kapitalis ditandai antara lain penguasaan atau kepemilikan faktor-faktor produksi oleh swasta, sedangkan pembuatan keputusan apa yang ingin diproduksikan berada di tangan siapa yang memiliki faktor produksi tersebut. Keputusan yang dibuat, dipandu oleh mekanisme pasar yang menyediakan informasi yang diperlukan sementara insentif kebendaan (material incentives) menjadi motivator utama bagi para pelaku ekonomi. Sistem ini sering dilawankan dengan sistem sosialisme, yang secara akademik dapat dibagi menjadi 2 (dua), yaitu sosialisme pasar dan sosialisme terencana. ${ }^{16}$

Sistem ekonomi Pancasila, mempunya faktor dan ciri yang tidak sama sehubungan dengan sistem-sistem diatas. Secara normatif, ketentuan Pasal 33 UUD 1945 sering dipahami sebagai sistem ekonomi yang layak dipakai oleh bangsa Indonesia. Pada Pasal 33 ayat (1) misalnya, menyebutkan bahwa perekonomian nasional disusun sebagai usaha bersama berdasarkan asas kekeluargaan. Asas ini dapat dipandang sebagai asas bersama (kolektif) yang bermakna dalam konteks sekarang yaitu

\footnotetext{
14. Eka Dharmaputra, 1987, Pancasila: Identitas dan Modernitas, TinjauanEtis dan Budaya, Jakarta, BPK Gunung 15. Mulia, hlm 13.

15. H.M. Safi'I, Op.cit, hlm 66.

16. Gregory dan Stuart, 1992, Comparative Economic System, Fourth Edition, Boston, Houghton Mifflin Company, hlm. 300 .
} 
persaudaraan, humanisme, dan kemanusiaan. Artinya ekonomi tidak dipandang sebagai wujud sistem persaingan liberal ala Barat, tetapi ada nuansa moral dan kebersamaannya, sebagai refleksi dari tanggung jawab sosial. Jika dicermati, maka keseluruhan norma dalam Pasal 33 UUD 1945 dewasa ini ternyata tidak dekat dengan ide pasar, efisiensi atau globalisasi. Beberapa istilah lebih dekat dengan faham sosial demokrasi, misalnya, kebersamaan, berkelanjutan, berwawasan lingkungan, dan kemandirian. Nilai-nilai itu muncul sebagai reaksi terhadap perkembangan ekonomi global ${ }^{17}$

Untuk menetapkan sistem ekonomi Pancasila sebagai sistem ekonomi Indonesia memang tidak mudah, karena selama ratusan tahun kita telah mengkonsumsi sistem hukum ekonomi yang berkualitas liberal atau mengabdi pada kepentingan negara-negara kapitalis. Sebenarnya setiap produk peraturan perundang-undangan bidang ekonomi sudah mencantumkan Pasal 33 UUD 1945 sebagai dasar hukum, namun demikian pasal-pasal yang ada di dalam perundang-undang tersebut belum secara konsisten senafas dengan amanat konstitusi. Bahkan tidak jarang isi pasal-pasalnya justru bertentangan.. Dengan adanya ketegasan ini di harapkan pembangunan hukum ekonomi bisa menghasilkan peraturan perundangundangan bidang ekonomi yang tidak hanya mengabdi pada pasar bebas dan meresposn keingan konglomerat atau perusahaanperusahaan transnasional, tapi lebih mengutamakan asas kekeluargaan untuk kemakmuran rakyat. ${ }^{18}$

Terkait perlindungan kepentingan rakyat, tampaknya komitmen negara dengan dipertahankannya Pasal 33 UUD 1945 dalam amandemen konstitusi. Bahkan, pasal ini diperkuat. Namun, kadang kala persoalannya bukan pada ada atau tidak adanya amanat konstitusi, tetapi lebih pada komitmen kita untuk mewujudkannya.

\section{Reposisi Makna Globalisasi Berhadapan Dengan Hukum Lokal}

Globalisasi mendorong dan mengubah konfigurasi hukum yang kompleks. Ketika keterkaitan global semakin meningkat, maka transaksi dan komunikasi lintas batas pun semakin meluas sehingga muncul kebutuhan untuk menciptakan hukum lintas negara (transnational rules). Globalisasi juga telah membawa pada meningkatnya ekspansi rezim hukum privat di arena global semakin banyak memproduksi hukum-hukum substantif tanpa adanya campur tangan negara, dan tanpa perlu legitimasi hukum dari negara atau perjanjian internasional.

Globalisasi adalah juga persebaran dan konvergensi nilai, konsep, dan hukum dari berbagai penjuru dunia menuju berbagai penjuru dunia. Globalisasi tidak hanya diindikasikan oleh borderless state, tetapi juga borderless law. ${ }^{19}$ Hukum dari wilayah tertentu dapat menembus ke wilayah-wilayah lain yang tanpa batas. Hukum internasional dan transnasional dapat menembus ke wilayah negara-negara manapun, bahkan wilayah lokal yang manapun di akar rumput. Atau sebaliknya, bukan hal yang mustahil bila hukum dan prinsip-prinsip lokal diadopsi sebagian atau seluruhnya menjadi hukum berskala internasional. ${ }^{20}$

Dalam perspektif global, pluralisme hukum menjadi semakin kompleks karena hadirnya hukum internasional dan transnasional dalam arena sosial tertentu, khususnya bidang humanitarian dan bisnis. Globalisasi tidak dapat diartikan lagi sebagai "perjalanan satu arah dari Barat ke Timur" melalui penyebaran nilai dan konsep demokrasi, hak asasi manusia beserta instrumen hukumnya. Globalisasi adalah juga persebaran nilai, konsep, dan hukum dari berbagai penjuru dunia menuju berbagai penjuru dunia. Globalisasi tidak hanya diindikasikan oleh borderless state, tetapi juga borderless law. Hukum dari wilayah tertentu dapat menembus ke wilayah-wilayah

17. Joni Emirzon, "Strategis Hukum Dalam Pembangunan Hukum Ekonomi Indonesia Di Era Globalisasi”, Jurnal Hukum Progresif, Vol. 2, No. 2, Oktober 2016, hlm. 60

18. Adi Sulistiyono, "Pembangunan Hukum Ekonomi Untuk Mendukung Pencapaian Visi Indonesia 2030", Pidato

19abatan Guru Besar, Fakultas Hukum, UNS, hlm 12 .

19. Maryanto, "Urgensi Pembaruan Sistem Hukum Ekonomi Indonesia Berdasarkan Nilai-nilai Pancasila", Jurnal

20. Yustisia, Edisi 91, Jan-Apr 2015, hlm 129-138

Sulistyowaty Irianto, 2009, Menuju Pembangunan Hukum Pro Keadilan Rakyat, Yayasan Obor, hlm 18. 
lain yang tanpa batas.

Di pihak lain, pertemuan antara berbagai sistem hukum dapat juga ditunjukkan dari adanya hukum nasional yang mengadopsi substansi traktat internasional, khususnya dalam bidang humanitarian. Menariknya, ide-ide mengenai "keadilan" dari berbagai penjuru dunia, lokal, dapat menjadi bagian dari instrumen hukum internasional yang dirumuskan secara bersama oleh banyak delegasi negara, dan mengikat bagi negara-negara yang meratifikasinya. Sebagai contoh adalah Konvensi CEDAW (Konvensi Penghapusan Segala Bentuk Diskriminasi terhadap Wanita), yang disahkan tahun 1979 dan saat ini sudah diratifikasi oleh lebih dari 180 negara.

\section{Implementasi dalam Pembaharuan Hukum Ekonomi.}

Berkaitan dengan pengaruh sistem hukum dalam pembuatan perundangundangan bidang ekonomi, menurut Adi Sulistiyono pada saat sekarang ini sistem hukum di Indonesia sedang mengalami 'tarikan dari atas dan bawah'. Tarikan dari bawah bisa dijelaskan sebagai berikut. Walaupun sekarang ini common law mendominasi tradisi hukum di Indonesia, namun setelah undang-undang otonomi daerah diberlakukan sejak tahun 2001, sistem hukum adat dan sistem hukum Islam juga akan memperlihatkan identitasnya sebagai nilai-nilai yang patut diperhitungkan kebangkitannya di daerah-daerah tertentu. Jadi dengan perkataan lain, tarikan dari bawah terhadap sistem hukum di Indonesia berupa munculnya trend 'mikro nasionalisme sistem hukum' di beberapa daerah di Indonesia. ${ }^{21}$

Dalam rangka membangun sistem hukum nasional, termasuk hukum ekonomi nasional itu pemerintah menetapkan kebijakan untuk memanfaatkan tiga sistem hukum yang eksis (living law) di Indonesia, yaitu sistem hukum adat, Islam dan Barat sebagai bahan bakunya. ${ }^{22}$ Pada era masa ketiga sistem hukum itu tidak bersifat konvergen, sering dihadapkan sebagai sistem-sistem hukum ynga saling bermusuhan. Kondisi konflik itu tidak terjadi secara alami tetapi sengaja diciptakan. Konflik-konflik hukum mengandung arti konflik-konflik nilai-nilai sosial budaya yang timbul secara wajar. Jika ada pertemuan antara dua atau lebih sistem nilai yang asing bagi suatu masyarakat, akan selalu selesai dengan wajar karena setiap masyarakat mempunyai daya serap dan daya penyesuaian terhadap konflik-konflik sistem nilai tersebut.

Selama ini kekuatan global berhasil melakukan penetrasi ke dalam hukum ekonomi Indonesia. Akibatnya, aturan hukum di bidang ekonomi yang digunakan sebagai landasan untuk melakukan pembangunan ekonomi di Indonesia banyak yang bercorak kapitalistik. Hukum ekonomi yang kapitalistik tersebut jelas bertentangan dengan UUD 1945. Untuk itu harus dilakukan pembaruan hukum ekonomi, baik konvergensi ataupun harmonisasi agar tetap sesuai dengan nilai-nilai Pancasila dan UUD 1945 tanpa meninggalkan kemampuannya dalam merespon kekuatan global.

\section{Simpulan}

Berdasarkan uraian pembahasan masalah di atas, maka dapat disampaikan simpulan sebagai berikut: (1). Dalam era globalisasi konflik kepentingan antara negara maju dan berkembang tidak dapat dielakan. Dalam pertarungan tersebut, terjadi dominasi dan hegemoni pemusatan ekonomi oleh negara-negara maju, kepada negara sedang berkembang atau miskin; (2). Pengaruh konvergensi sistem ekonomi Indonesia membutuhkan sistem ekonomi yang akomodatif, yang tidak memisahkan secara kategoris antara ekonomi pasar kapitalistik dan sosialis, dalam pembaharuan hukum ekonomi Indonesia.

\section{Daftar Pustaka}

\section{Adolf Huala, 2002, Hukum Ekonomi Internasional Suatu Pengantar, Jakarta, Rajawali Pers . \\ Bariroh Laili, "Politik Hukum Nasional Dan}

\footnotetext{
21. Adi Sulistiyono, Op. cit, hlm 14.

22. Syam, M Husni. "Perlunya Pembaharuan Hukum Ekonomi Indonesia Yang Tanggap Terhadap Perubahan Pembangunan”, Jurnal Sosial dan Pembangunan, Vol. 16, No. 4, dec. 2000, hlm. 370-410.
} 
Hegemoni Globalisasi Ekonomi”, Jurnal Review Politik, Vol. 2, No.2, Desember 2012.

Dharmaputra Eka, 1987, Pancasila: Identitas dan Modernitas, TinjauanEtis dan Budaya, Jakarta, BPK Gunung Mulia.

Emirzon Joni, "Strategis Hukum Dalam Pembangunan Hukum Ekonomi Indonesia Di Era Globalisasi", Jurnal Hukum Progresif, Vol.2, No.2, Oktober 2016.

Fakrulah Zudan Arief, 2000, Membangun Hukum Yang Berstruktur Sosial Indonesia Dalam Kancah Trends Globalisasi, Bandung, PT. Citra Aditya Bakti.

Hidayat Arief, "Bernegara Itu Tidak Mudah: Dalam Perspektif Hukum dan Politik", Pidato Pengukuhan Jabatan Guru Besar, Universitas Diponegoro Semarang.

Irianto Sulistyowaty, 2009, Мепијu Pembangunan Hukum Pro Keadilan Rakyat, Yayasan Obor.

Maulana Zain, 2010, Jerat Globalisasi Neoleberal; Ancaman Negara Dunia Ketiga, Yogyakarta, Biak.

Maryanto, "Urgensi Pembaruan Sistem Hukum Ekonomi Indonesia Berdasarkan Nilai-nilai Pancasila”, Jurnal Yustisia, Edisi 91, Januari-April 2015.

Sulistiyono Adi, "Pembangunan Hukum Ekonomi Untuk Mendukung Pencapaian Visi Indonesia 2030”, Pidato Jabatan Guru Besar, Fakultas Hukum, UNS.

Safi'I H.M., 2009 , Perencanaan Pembangunan Daerah (Kajian dan Aplikasi Rencana Pembangunan Jangka Menengah Daerah (RPJMD) di Kabupaten Hulu Sungai Selatan), Malang, Averroes Press.

Syam M. Husni, "Perlunya Pembaharuan Hukum Ekonomi Indonesia Yang Tanggap Terhadap Perubahan Pembangunan", Jurnal Sosial dan Pembangunan, Vol. 16, No. 4, Desember 2000.

Siahaan Nimrot, "Pengaruh Hukum Terhadap Globalisasi Dan Pembangunan Ekonomi", Jurnal Ilmiah "Research
Sainis", Vol. 1, No. 1, Januari 2015.

Wahono Francis, 2003, Neoliberalisme, Yogyakarta. Cindelaras Pustaka Rakyat Cerdas. 